\title{
REVIEW
}

\section{Genetic regulation in pubertal delay}

\author{
Sasha R Howard
}

Centre for Endocrinology, William Harvey Research Institute, Barts and the London School of Medicine and Dentistry, Queen Mary, University of London, London, UK

\section{Correspondence should be addressed to S R Howard: s.howard@qmul.ac.uk}

\begin{abstract}
Delayed puberty represents the clinical presentation of a final common pathway for many different pathological mechanisms. In the majority of patients presenting with significantly delayed puberty, there is a clear family history of delayed or disturbed puberty, and pubertal timing is known to be a trait with strong heritability. Thus, genetic factors clearly play a key role in determining the timing of puberty, and mutations in certain genes are recognised as responsible for delayed or absent puberty in a minority of patients. Through the identification of causal genetic defects such as these we have been able to learn a great deal about the pathogenesis of disrupted puberty and its genetic regulation. Firstly, deficiency in key genes that govern the development of the gonadotropin-releasing hormone system during fetal development may result in a spectrum of conditions ranging from isolated delayed puberty to absent puberty with anosmia. Secondly, a balance of inhibitory and excitatory signals, acting upstream of GnRH secretion, are vital for the correct timing of puberty. These act to repress the hypothalamic-pituitary-gonadal axis during mid-childhood and allow it to reactivate at puberty, and alterations in this equilibrium can cause delayed (or precocious) puberty. Thirdly, disturbances of energy metabolism inputs to the kisspeptin-GnRH system may also lead to late onset of puberty associated with changes in body mass.
\end{abstract}

Key Words
- puberty
- puberty genetics
- delayed puberty
- constitutional delay in
puberty
- EAP1

\section{Introduction}

Delayed onset of puberty is one of the commonest conditions presenting to the paediatric endocrinologist, and in both genders is most frequently due to self-limited delayed puberty (Sedlmeyer \& Palmert 2002, Abitbol et al. 2016). The term self-limited refers to the fact that these patients will have an onset of puberty before the age of 18 years, either spontaneously or induced with a short course of sex steroids. Moreover, in patients with this phenotype there are no recognised features of hypogonadism or infertility in adulthood. This isolated pubertal delay has historically been termed constitutional delay in growth and puberty, as it is often seen in young people who have had slow growth since early childhood. However, not all those presenting with delayed puberty will display these constitutional features and thus the name may not always be accurately applied to this condition.

Young people who remain prepubertal, at Tanner stage B1 in girls (absence of breast budding) or Tanner stage G1 in boys (with testicular volumes less than $4 \mathrm{~mL}$ ), at an age that is 2-2.5 standard deviations (s.D.) later than the population mean are classified are having delayed puberty (Palmert \& Dunkel 2012). Those with delayed or faltering progression through puberty, identification of which can be aided by the use of puberty normograms, need to be carefully reviewed for isolated delayed puberty (Lawaetz et al. 2015). However, it is also important to consider other differential diagnoses including organic causes. Self-limited delayed puberty is currently a diagnosis of 
exclusion, and three other main pathologies need to be considered. These are primary gonadal failure, due most commonly to Turner or Klinefelter syndrome; GnRH or gonadotropin deficiency, either acquired for example secondary to a brain tumour or congenital in the form of hypogonadotropic hypogonadism or Kallmann syndrome (hypogonadotropic hypogonadism with anosmia) and functional hypogonadotropic hypogonadism due to chronic illness (such as chronic renal failure, sickle cell disease or cystic fibrosis), excessive exercise, malnutrition or deprivation (Sedlmeyer \& Palmert 2002).

Delayed puberty has often been thought of as more common in boys, but published evidence suggests that there may be an equal number of males and females with self-limited delayed puberty when family members are reviewed (Wehkalampi et al. 2008). One study has even showed a reverse ratio with a higher number of female relatives affected with delayed puberty (Winter et al. 2016). Within the probands there is still a preponderance of boys, pointing to referral bias as the reason for more male patients being seen in the clinical setting.

Self-limited delayed puberty is often seen in multiple generations of the same family, a feature that may help in reaching the diagnosis. Most commonly, the trait is inherited in an autosomal dominant pattern, not always with complete penetrance, but also autosomal recessive, $\mathrm{x}$-linked and bilineal pedigrees have been observed (Sedlmeyer et al. 2002, Wehkalampi et al. 2008). It is clear from epidemiological research including twin studies in both genders that the timing of puberty is strongly heritable and that genetic regulation is an important element in determining when healthy individuals enter puberty (Eaves et al. 2004, van den Berg et al. 2006, Morris et al. 2011). However, evidence from genome wide association studies (GWAS) suggests that a large number of different genetic signals play a role in the variation of pubertal timing that is observed in the general population (Day et al. 2017). In contrast, familial delayed puberty may be inherited via one, or a small number of genetic defects in each family, with a corresponding autosomal dominant inheritance pattern. Both GWAS and nextgeneration sequencing of disease cohorts have shed light on the genetic basis of pubertal timing, as will be discussed in this review.

\section{Single gene defects leading to delayed and disordered puberty}

The first information about single gene defects producing a phenotype of delayed puberty came from investigations of families with hypogonadotropic hypogonadism or Kallmann syndrome (Table 1). In these pedigrees, family members were seen with isolated delayed puberty, in some cases with the same genetic mutation as the proband with GnRH deficiency or resistance, and in others with less deleterious genetic changes (for example, a heterozygous change whilst the proband was homozygous for the same mutation). Such situations have been seen in families with mutations in the genes FGFR1, GNRHR and HS6ST1 (Lin et al. 2006, Pitteloud et al. 2006, Tornberg et al. 2011). In many of these genes the phenomenon of allelic heterogeneity is displayed, where different mutations in the same gene lead to varying phenotypes along a range of disease severity. For example, complete loss-of-function mutations in the GNRHR gene are associated with severe hypogonadism due to exonic nonsense changes or even imprinting defects such as maternal uniparental isodisomy (Cioppi et al. 2019), whereas mutations leading to partial deficiency show a wide spectrum of clinical manifestations including the 'fertile eunuch' phenotype, partial hypogonadotropic hypogonadism and isolated delayed puberty (Pitteloud et al. 2001, Chevrier et al. 2011, Vaaralahti et al. 2011).

Defects in genes further downstream in the hypothalamic-pituitary-gonadal axis may also result in a number of different phenotypes. Mutations in the genes encoding the luteinising hormone and follicle-stimulating hormone beta-subunits and their receptors present with a spectrum of disease severity including delayed puberty, primary amenorrhea, hermaphroditism, infertility and hypogonadism in males and females (Layman et al. 1997, Themmen \& Huhtaniemi 2000, Narayan 2015, Potorac et al. 2016, Szymanska et al. 2018).

Some evidence for mutations in genes known to be associated with congenital hypogonadotropic hypogonadism causing isolated delayed puberty has been found by sequencing these GnRH deficiency genes in delayed puberty cohorts (Fig. 1). Potentially pathogenic variants in GNRHR, TAC3 and its receptor TACR3, IL17RD and SEMA3A have been identified by whole exome sequencing (Zhu et al. 2015). However, without in vitro or in vivo evidence of pathogenicity for these variants, it is difficult to know definitively if they are disease causing.

A study comparing the frequency of mutations in $24 \mathrm{GnRH}$ deficiency genes between a cohort of probands with isolated delayed puberty and a cohort with congenital hypogonadotropic hypogonadism $(\mathrm{CHH})$ found the latter to have a significantly higher proportion of mutations ( $7 \%$ of delayed puberty probands vs $51 \%$ 
Table 1 Genetic causes of syndromic and non-syndromic delayed puberty.

\begin{tabular}{l}
\hline Phenotype \\
\hline Non-syndromic \\
Self-limited delayed puberty or \\
hypogonadotropic hypogonadism \\
Self-limited delayed puberty or \\
hypothalamic amenorrhea \\
Self-limited delayed puberty \\
Self-limited delayed puberty with \\
constitutional features \\
Syndromic \\
Delayed puberty or hypogonadism with \\
learning difficulties and obesity
\end{tabular}

of $\mathrm{CHH}$ probands, $\left.P=7.6 \times 10^{-11}\right)$. There was also a higher proportion of oligogenicity in the cohort with hypogonadotropic hypogonadism (Cassatella et al. 2018). The low level of mutations in these genes in the delayed puberty group points to a genetic basis of isolated pubertal delay that is in large part different to that of GnRH deficiency disorders.

Over the last few years, two genes involved in the regulation of GnRH neuron development have been implicated in self-limited delayed puberty (Table 1). The first of these is IGSF10, a member of the immunoglobulin

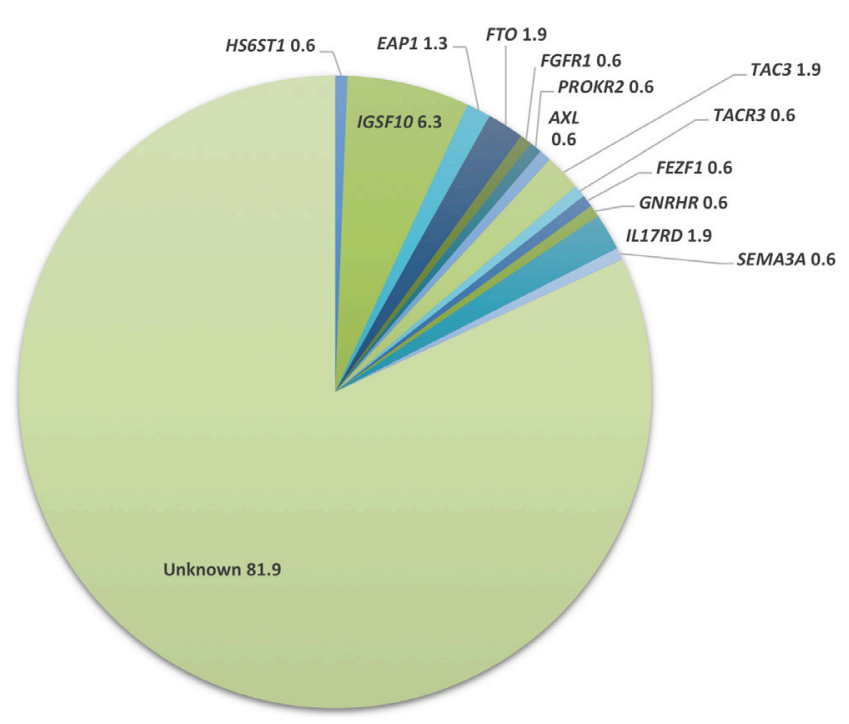

Figure 1

Genes identified with importance for the pathogenesis of self-limited delayed puberty. Gene names are shown in italics, with percentage of probands from cohorts with self-limited delayed puberty carrying potentially pathogenic variants in these genes, based on data from published studies (Zhu et al. 2015, Howard et al. 2016, 2018a,b, Cassatella et al. 2018, Mancini et al. 2019). Over $80 \%$ of patients with isolated delayed puberty currently do not have a genetic cause identified. superfamily, identified by whole exome and targeted resequencing in a large Finnish delayed puberty familial cohort (Howard et al. 2016). The two pathogenic mutations, found in six unrelated families, affected the extracellular secretion of IGSF10. Whole gene knockdown disturbed the migration of immortalised GnRH neurons in vitro and disrupted in vivo development of the GnRH system in zebrafish embryos. This work proposed the concept that defects of GnRH neuronal migration during embryonic development could present with a phenotype of delayed puberty in adolescence, both without previous constitutional delay in growth, and with subsequent normal reproductive capacity (Fig. 2).

The hypothesis is that an insult to the developing GnRH neurosecretory network would lead to reduced numbers, or mis-timed arrival, of GnRH neurons at the hypothalamus. Thus, there would be a functional impairment of the hypothalamic neuroendocrine system with a higher 'threshold' for the onset of puberty, and a subsequent delayed pubertal timing. More recently

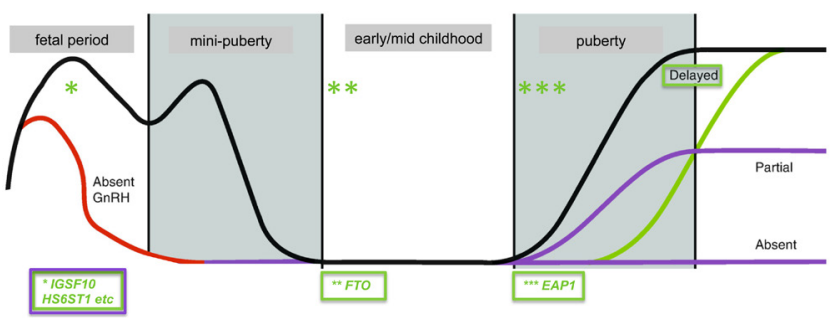

Figure 2

Hypothalamic-pituitary axis dynamics. Schematic displaying the dynamic activity of the hypothalamic-pituitary axis in different pre- and postnatal periods. Genetic defects may result in delayed puberty due to effects in the fetal, early or later childhood periods. Deficiency of some genes, such as HS6ST1, may result in either delayed, partial or absent puberty, due to allelic heterogeneity and other factors. Green - relating to delayed puberty, Purple - relating to partial or absent puberty. 


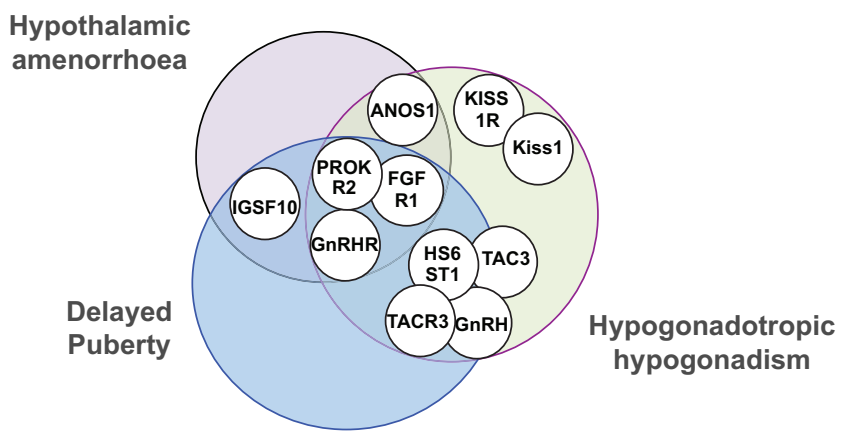

Figure 3

Overlap between genetic basis of delayed puberty, hypogonadotropic hypogonadism and hypothalamic amenorrhoea.

IGSF10 mutations have been identified in a separate study in a cohort with both premature ovarian insufficiency and neuronal development defects and also in a further proband with a hypogonadotropic hypogonadism-type phenotype (Jolly et al. 2019).

In the first IGSF10 study, mutations were additionally found in patients with adult-onset functional hypogonadotropic hypogonadism. In terms of genetic regulation, a potential overlap between hypogonadotropic hypogonadism and other forms of functional hypogonadism such as hypothalamic amenorrhoea has already been identified (Caronia et al. 2011, Cangiano et al. 2019, Dwyer et al. 2019), and this IGSF10 work points also to a potential shared genetic basis of delayed puberty and hypothalamic amenorrhoea (Fig. 3).

The second gene identified, with a mutation in a large family from the same familial delayed puberty cohort, was the GnRH deficiency gene HS6ST1 (Howard et al. 2018b). The pathogenic mutation was found by next-generation sequencing to be carried by six family members from three generations. All had heterozygous carriage of this missense mutation and had typical features of isolated delayed puberty, with no short stature in early childhood or at adult height. Moreover, no family members had phenotypic features of hypogonadotropic hypogonadism. Mouse experiments demonstrated that heterozygous loss of Hs6st1 caused delayed puberty, with female mice having significantly late vaginal opening, a marker of pubertal onset in female rodents. Like the human patients, however, the mice showed no fertility defects, with normal testes size and development in males and normal litter size for both genders.

Interestingly, the mice with heterozygous Hs6st1 deficiency had a similar number of GnRH neurons in the adult hypothalamus as compared to WT mice. As Hs6st1 mRNA is highly expressed in both the arcuate nucleus and paraventricular nucleus, where KNDy (kisspeptin, neurokinin $\mathrm{B}$ and dynorphin) neurons and tanycytes are known to regulate GnRH secretion and function (Pielecka-Fortuna et al. 2008, Parkash et al. 2015), HS6ST1 may modulate GnRH neuronal activity or other relevant downstream pathways. Together the findings in these two genetic studies point to a potential fetal origin of isolated delayed puberty. Furthermore, they lend weight to the evidence for allelic heterogeneity of the hypothalamicpituitary-gonadal axis; where mutation of single allele of a gene can cause self-limited delayed puberty, but more severe defects of the same gene, or in combination with additional gene defects, lead to GnRH deficiency phenotypes (Pitteloud et al. 2007).

\section{GWAS in pubertal timing}

Very large meta-analyses of GWAS of timing of age of menarche in over 370,000 women using directly sequenced and imputed genotype data have isolated 389 independent signals significant associated with age at puberty $\left(P<5 \times 10^{-8}\right)$ (Day et al. 2017). Each of these alleles has an effect size on timing of menarche of between 1 week and 5 months. In total the loci of the largest and most recent study explains $\sim 7.4 \%$ of the variation in the timing of age of menarche in the general population. This corresponds to approximately $25 \%$ of the estimated heritability of pubertal timing (Day et al. 2017). These results point at a conclusion that the majority of these genetic variants in isolation have a low impact and that there is a large degree of heterogeneity in the genetic determinants of normal pubertal timing. The data are applicable to male puberty as well as to female, as many of the signals show a significant association with Tanner staging in both genders and have consistent effects on age at voice breaking. Of note, the signals identified have stronger effects on early than on late age of female puberty, whilst in male puberty, they have larger effect estimates for relatively late voice breaking (Day et al. 2017).

Interestingly, there is an overlap between those genetic loci identified by GWAS of timing of puberty and the genetic basis of hypogonadotropic hypogonadism and Kallmann syndrome, including the genes TACR3, LEPR and KISS1 (Day et al. 2017). Furthermore, there are also common genes found between these GWAS of age at menarche and voice break, and mutations discovered in pedigrees with precocious puberty, namely MKRN3 and DLK1 (Abreu et al. 2015, Simon et al. 2016, Dauber et al. 2017, Day et al. 2017). It, therefore, would appear plausible that genes, deficiency of which are responsible 
for isolated delayed puberty, may also have been pulled out via genome wide association techniques.

The gene FTO was the first and largest signal to be associated with obesity via GWAS, and has been also identified through GWAS of age at menarche (Yeo 2014). FTO was already known from animal models to regulate food intake and be an important component of the energy homeostasis pathways (McMurray et al. 2013, Merkestein et al. 2015). FTO expression is itself modulated by levels of essential amino acids, and FTO serves to regulate mTORC1 signalling based on these levels (Fischer et al. 2009, Speakman 2015). mTOR in turn acts to couple energy balance and the hypothalamic expression of Kiss1, thus modulating the hypothalamic-pituitary axis on the basis of its metabolic environment (Martinez de Morentin et al. 2014). This is evidenced in rodent studies by delayed vaginal opening, a proxy of the timing of puberty onset, secondary to blockade of mTOR.

The first human mutations in FTO associated with pubertal timing were identified recently in patients with self-limited delayed puberty associated with extreme low BMI and maturational delay in growth in early childhood (Howard et al. 2018a). In the same study, a murine model of heterozygous deficiency of FTO displayed significantly delayed puberty timing but without marked reduction in body mass. It is not known, however, if FTO exerts its effect on pubertal onset via its influence on body mass, or by modulation of mTOR signalling, or both.

In contrast, several fascinating candidate genes from the aforementioned GWAS have not, as yet, been found to be causal in human delayed puberty (Tommiska et al. 2010) or early puberty (Silveira-Neto et al. 2012). An example of this is the human gene LIN28B, an orthologue of a controller of developmental timing in the worm Caenorhabditis elegans, which was the first clear signal to be found via age of menarche GWAS (Ong et al. 2009). A SNP rs314276 from intron 2 of the LIN28B gene was associated with an earlier age of both breast bud formation and menarche. This family of proteins regulates, and is regulated by, a key family of miRNAs named let-7 (Liu et al. 2015, Corre et al. 2016). No mutations in LIN28B have as yet been found in patients with pubertal disorders.

\section{Pubertal timing and metabolic regulation}

There is strong evidence that timing of puberty is linked to energy balance and that higher BMI, particularly in girls, is associated with earlier puberty (He \& Karlberg 2001, Wang 2002, Sorensen et al. 2010). This interplay between metabolism and the hypothalamic-pituitary-gonadal axis is thought to go some way to explain the secular trend toward an earlier age of pubertal onset that has been noted for some time in the developed world. One of the important signals of energy sufficiency is the metabolic hormone leptin, which is a permissive signal for puberty. Leptin is required for reproductive health both in humans and mice, where lack of the hormone or its receptor lead to pubertal failure and infertility (Farooqi 2002, Nunziata et al. 2019). Despite the observation that in females serum leptin concentrations rise during puberty (Ahmed et al. 1999), levels are lower in males and decrease during puberty (Garcia-Mayor et al. 1997), and it is not thought to be the key coordinator in the amplification of $\mathrm{GnRH}$ signalling pathways at pubertal onset.

Apart from mutations in FTO and in the leptin gene as discussed earlier, rare pathogenic variants in genes which regulate body mass have rarely been shown to lead to delayed puberty in humans. However, a substantial fraction of common variants affecting BMI also have significant associations in genome wide studies of timing of puberty (Day et al. 2015). There is recent evidence that $\alpha-\mathrm{MSH}$ signalling may have a key role in the metabolic control of puberty. $\alpha$-MSH acting on MC3/4 receptors increase Kiss1 expression and mediate the permissive effects of leptin on puberty (Manfredi-Lozano et al. 2016). Ghrelin and other gut-derived peptides may also contribute to the pathways by which energy homeostasis modulates the reproductive axis (Fernandez-Fernandez et al. 2006, Pomerants et al. 2006). A small number of patients with delayed puberty were found to have mutations in the ghrelin receptor or growth hormone secretagogue receptor (GHSR) (Pugliese-Pires et al. 2011).

Mutations in one of the newest GnRH deficiency genes $K L B$, which encodes beta-klotho and is part of the metabolic FGF21/KLB/FGFR1 pathway, have been demonstrated to cause hypogonadotropic hypogonadism in association with metabolic defects such as obesity and insulin resistance (Xu et al. 2017). In mouse models, both deficiency of $\mathrm{Klb}$ and overexpression of Fgf21 lead to delayed puberty and subfertility (Owen et al. 2013, Xu et al. 2017), reinforcing the importance of energy homeostasis for reproductive axis function. Interestingly, a small number of the relatives from these pedigrees carrying $K L B$ mutations had a phenotype of isolated delayed puberty without $\mathrm{CHH}$ features.

\section{Regulatory control of the GnRH network}

After the fetal and postnatal (known as the mini-puberty) activity of the hypothalamic-pituitary-gonadal axis, there 
is a long period of mid-childhood quiescence where the GnRH network is minimally active (Lanciotti et al. 2018). Around the time of puberty onset, central inhibition of this neuroendocrine system decreases, and there is a marked upregulation in the GnRH pulse generator activity. This change is brought about by a number of factors. Firstly, there are alterations in the balance of GABA-glutamate signalling in the brain (Bourguignon et al. 1997). Secondly, GnRH neurons undergo morphological changes with increased dendritic spine density and a simplification of their dendritic architecture. Thirdly, and perhaps most importantly, kisspeptin signalling, one of the key stimulatory input to GnRH activity, is intensified at this time. This is due (at least in mouse and primate models) to increased kisspeptin synthesis in KNDy neurons in the arcuate nucleus and to an increase in the GnRH neuronal responsiveness to kisspeptin stimulation (Plant \& BarkerGibb 2004).

However, mutations in Kiss1 and its receptor have not been commonly found to be responsible for disorders of pubertal timing (Chan et al. 2009, Silveira et al. 2010, Topaloglu et al. 2012). This would suggest that kisspeptin is not the ultimate controller of pubertal timing and that we instead need to search for what triggers this upregulation of kisspeptin biosynthesis in the hypothalamus at this critical time. Kisspeptin is influenced by and acts to coordinate a further cascade of upstream stimulators and repressors, the balance of which also contribute to the puberty brake and its release (Fig. 4) (Plant 2015). This includes a complex system of transcription factors which act as repressors and activators of Kiss 1 and GnRH1 transcription, and which is in turn regulated by a number of different epigenetic mechanisms including DNA methylation, histone modification and non-coding RNAs (Kurian et al. 2010, Lomniczi et al. 2013, Messina et al. 2016, Toro et al. 2018).

Both systems biology approaches (Ojeda et al. 2010) and animal models (Plant 2015) have proposed several candidates for these upstream controllers, but there have been little data from human subjects. Potential key regulators include transcriptional repressors, particularly those containing zinc finger motifs, which act to regulate gene expression in mammals (Lomniczi et al. 2015, Gabriele et al. 2017). Two homeobox genes, Oct-2 and $T t f-1$, have been shown to have increased expression in the early juvenile period in animal models (Lee et al. 2001). Oct-2 deficiency leads to delayed age at first ovulation in mice whilst overexpression induces precocious puberty (Ojeda et al. 1999). Ttf-1 acts to increase GnRH expression (Mastronardi et al. 2006).

Ttf-1 activates a further nuclear transcription factor, Eap1, and levels of Eap1 mRNA also increase in the hypothalamus of primates and rodents during puberty. EAP1 binding to the GnRH1 promoter increases in monkey hypothalamus at the onset of puberty (Mancini et al. 2019). Furthermore, knockdown of Eap1 with siRNAs causes delayed puberty and disrupted estrous cyclicity in rodents (Heger et al. 2007, Dissen et al. 2012, Lomniczi et al. 2012, Xu \& Li 2016, Li \& Li 2017). Eap1 has dual transcriptional activity: it trans-activates the

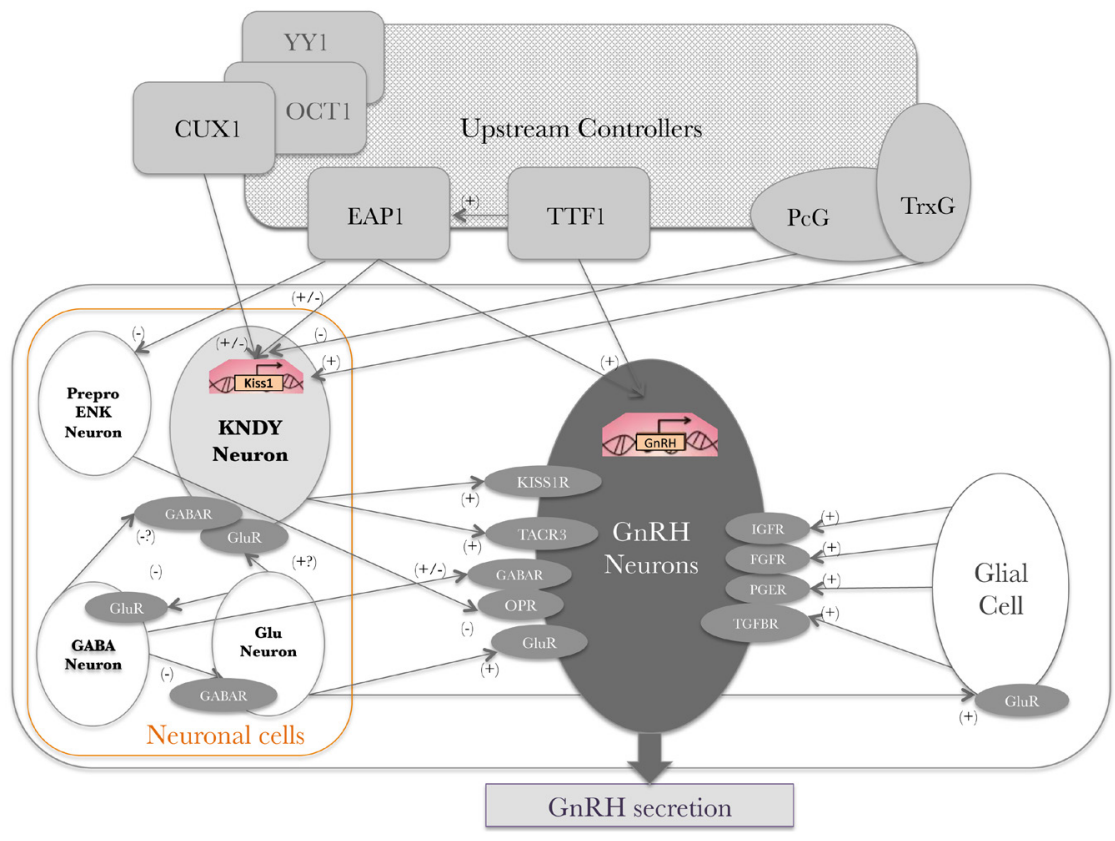

\section{Figure 4}

Upstream regulators of the $\mathrm{GnRH}$ neuroendocrine network at the onset of puberty. Upstream controllers act via transcriptional repression or enhancement of Kiss1 and GnRH expression. + represents an activating signal, represents a repressing signal; glu, glutamate; gluR, glutamate receptor; KNDY, KNDy neurons of the arcuate nucleus which coexpress kisspeptin, neurokinin B and dynorphin; PcG, polycomb group; TrxG, trithorax group. Original concept from (Ojeda et al. 2006). 
GnRH promoter, leading directly to increased GnRH secretion, and inhibits the preproenkephalin promoter, thus preventing repression of GnRH secretion. This points to a multifaceted system where activators can act directly on GnRH transcriptional activity or via hypothalamic Kiss1 expression to promote the initiation of puberty ( $\mathrm{Li}$ \& Li 2017). Eap1 gene expression is itself regulated by repression by two further transcriptional regulators, $Y y 1$ and Cux1 (Mueller et al. 2012).

EAP1 is the first of these proposed upstream regulators in which mutations have been found in human subjects with pubertal disorders (Mancini et al. 2019). Deleterious mutations in EAP1 carried by members of two families with classical clinical and biochemical features of selflimited delayed puberty were identified by whole exome sequencing. Both probands had late onset of puberty after 15.5 years with delayed peak height velocity, without syndromic features. Hypogonadotropic hypogonadism was excluded on the basis that the subjects had spontaneous pubertal development by the age of 18 years. The two mutations were both found at highly conserved residues and were translated into mutant proteins that had a reduced ability to trans-activate the GnRH promoter as compared to WT.

Regulation of the Kiss1 gene by the polycomb complex repressors EED and $\mathrm{Cbx} 7$ and the trithorax group of activators have been implicated as a further component of this system of transcriptional control (Fig. 4) (Lomniczi \& Ojeda 2016). Overexpression of EED represses GnRH expression and compromises fertility in rodents, an effect that is mediated via kisspeptin. These are termed bivalent genes, as their expression is repressed at some points during development and upregulated at others. Prior to puberty onset there is increased methylation of the promoters of these polycomb genes, resulting in a reduction in expression, as well as a decrease in the binding of EED on the Kiss1 promoter. In contrast, binding of the trithorax group protein MLL3 to the Kiss1 enhancer upstream of the promoter increases at puberty and leads to the recruitment of other components of the trithorax group, allowing these enhancer sites to be modified (Toro et al. 2018)

Moreover, there is also reorganisation of the chromatin status and changes in histone methylation to accompany the loss of these polycomb complex proteins from the Kiss1 promoter (Lomniczi et al. 2013), mediated in part via SIRT1. Deactylation of histones (via SIRT1) leads to decreased Kiss1 mRNA expression, and overexpression of SIRT1 leads to delayed puberty in a rodent model (Vazquez et al. 2018). Interestingly, nutritional status in the rodent model influences SIRT1 levels, and this may be a further mechanism by which metabolic inputs regulate pubertal timing. Studies on both rats and goats also provide data on changes in histone acetylation and gene methylation resulting in alterations in gene expression during puberty (Morrison et al. 2014, Yang et al. 2016).

\section{Imprinting, non-coding RNAs and chromosomal anomalies}

Imprinting is an important mechanism for the regulation of several key human developmental stages including weaning and adrenarche. In general, genes which are expressed from the paternal allele encourage later childhood maturation, whilst maternally expressed genes support earlier development (Peters 2014). The two principal parent-of-origin-specific signals that have been identified to date from GWAS of pubertal timing are both paternally inherited; however, maternally inherited polymorphisms may also exert effects on the timing of puberty (Day et al. 2017). The two paternally inherited genes identified via GWAS of timing of puberty, MKRN3 and $D L K 1$, are both associated with central precocious puberty (Abreu et al. 2013, Dauber et al. 2017, Day et al. 2017). Notably, MKRN3 encodes a further zinc finger protein with E3 ubiquitin ligase activity (Jong et al. 1999, Simon et al. 2016). MKRN3 expression in the arcuate nucleus declines in mice at weaning and in humans serum concentrations fall at puberty onset, suggesting an inhibitory role of $M K R N 3$ on the GnRH network during mid-childhood which is relaxed at puberty (Hagen et al. 2015, Busch et al. 2016). However, although clearly implicated in human precocious puberty, neither MKRN3 nor DLK1 mutations have been found in patients with delayed pubertal timing.

Prader-Willi syndrome (PWS) is classically caused by a disorder of imprinting, and patients with this condition often have either absent or delayed puberty (Hirsch et al. 2015). PWS is most commonly due to deletion of a cluster of imprinted genes (including MKRN3) on the paternally inherited copy of chromosome 15 (paternal deletion) or maternal uniparental disomy where both copies of this cluster are inherited from the mother (Butler 2009). Precocious puberty is unusual in PWS (Lee \& Hwang 2013), whereas most individuals show some pubertal disturbance ranging from poor growth in puberty, hypogonadotropic hypogonadism, undescended testes, underdeveloped genitalia or primary amenorrhea (Crino et al. 2003). The lack of MKRN3 expression is superseded by the inactivation of other genes in this complex, 
in particular MAGEL2, which act to delay pubertal timing (de Smith et al. 2009, Kanber et al. 2009). The clinical phenotype of pubertal abnormalities in PWS syndrome appears to be dependent on tissue-specific expression and timing of expression during development of these imprinted genes (Butler 2009, Peters 2014).

Non-coding RNAs also act as important epigenetic modulators of pubertal timing. Again, the evidence for this at present comes mostly from animal models, where particular miRNAs are important for upregulation of $\mathrm{GnRH}$ transcription during the murine equivalent of the human mini-puberty (Messina et al. 2016). The miRNAs (miR-200 and mIR-155) appear to regulate Gnrh1 synthesis in GnRH neurons, through regulation of two transcriptional repressors, Zeb-1 and Cebpb. miR-200 and mIR-155 activity lead to a reduction in Zeb-1 and Cebpb with a resultant increase in the transcriptional activation of GnRH1. There is also, as with the transcriptional regulators Eap1 and TTf1, in-built regulation of Zeb1 by Cebpb (Messina et al. 2016). Another miRNA, miR-7a2, is vital for normal pituitary development in mice, with deficiency resulting in a phenotype of hypogonadotropic infertility (Ahmed et al. 2017). Evidence for the role of these non-coding RNAs in human puberty is still to be discovered.

The chromosomal anomalies associated with pubertal disorders are commonly recognised in Turner and Klinefelter syndrome, and a full discussion of the causes of primary hypogonadism is beyond the scope of this text. However, clinicians also need to be aware of more subtle chromosomal anomalies such as isochromosome Yp, $\mathrm{i}(\mathrm{Yp})$, detectable via array comparative genomic hybridisation, which has a clinical presentation very similar to self-limited delayed puberty with pubertal delay and slow growth (Gaudino et al. 2019).

\section{Endocrine-disrupting chemicals and their influence on pubertal timing}

There is increasing concern about the role of endocrinedisrupting chemicals (EDCs) in human pubertal timing (Mouritsen et al. 2010). These EDCs are found in a wide variety of commonly used products, including polybrominated biphenyls, glyphosate and bisphenol A, as well as in common medicines including paracetamol and betamethasone (Parent et al. 2015, Pinson et al. 2017, Drobna et al. 2018, Milesi et al. 2018). There is evidence that EDC exposure in early or late childhood, or in utero, may influence the hypothalamic-pituitary-gonadal axis. Exposure to the oestrogenic insecticide DTT leads to premature onset of puberty in internationally adopted children (Krstevska-Konstantinova et al. 2001). Male infants exposed to phthalates during fetal development have increased rates of underdeveloped genitalia (Swan et al. 2005). In mouse models, there are data to support that EDCs given to pregnant mothers produce epigenetic changes in fetal testis as well as other systemic effects (Parent et al. 2015).

Evidence for EDCs affecting the central control of GnRH secretion is more limited, but female mice given arsenic in utero had altered hypothalamic expression not only of GnRH and LH but also of the upstream transcriptional regulators discussed earlier, such as Oct-2 and Ttf-1, with subsequent precocious puberty (Li et al. 2018). Whilst there is evidence that the human brain epigenome at puberty is affected by environmental disturbances (Morrison et al. 2014), in many cases, subjects are exposed to varying doses and combination of EDCs affecting oestrogenic, androgenic or other pathways, at different time points, so complicating the analysis of the effects of these chemicals (van den Driesche et al. 2015).

Importantly, most recently there is evidence from rodent models that the effects of EDCs may be heritable, as they are also present in the next two or more generations (Rissman \& Adli 2014). In particular, studies with vinclozolin, a commonly used fungicide, in mice show that it produces transgenerational changes to the epigenome (Nilsson et al. 2018). Second-generation female mice had significantly delayed puberty, and thirdgeneration males had increased rates of testis, prostate and kidney disease, as well as changes in the age of puberty onset.

\section{Conclusions}

The genetic control of human puberty comprises an intricate and multifaceted system with many interacting elements. A clear understanding of the genetic defects that result in abnormalities of pubertal timing, including delayed puberty, is hugely important to allow the optimal management of patients with these conditions, but also informs the understanding of the biology of normal pubertal timing. As we have seen from this overview, there is no one single gene that is capable of the hypothalamic control of puberty onset. Rather, a complex and multitiered balance of inhibitory and activating signals act together to apply the repressive control of the HPG axis seen in mid-childhood and to allow the brake to be released at puberty onset. Implicitly, the integrity of the GnRH neuroglial network upon which this brake is 
applied is also key for the correct timing of puberty, and gene defects resulting in erroneous fetal development of this neuroendocrine system can produce phenotypes from isolated delayed puberty to GnRH deficiency. Additionally, energy homeostasis has a vital influence on pubertal timing and deficiency of genes related to metabolic balance can lead to aberrations including delayed puberty. Moreover, gene-environment interactions mediated via epigenetic mechanisms also exert influence on the hypothalamic regulation of puberty, which may be heritable. The potential for translation of this knowledge has yet to be realised, but the hope is that it may aid rapid genetic diagnosis of different types of pubertal disorders, improve treatment options and inform the natural history of these conditions.

\section{Declaration of interest}

The author declares that there is no conflict of interest that could be perceived as prejudicing the impartiality of this review.

\section{Funding}

S R H is funded by the NIHR (CL-2017-19-002), The Rosetrees Trust (M222-F1), and supported by the Academy of Medical sciences, Wellcome Trust, Medical Research Council, British Heart Foundation, Arthritis Research UK and Diabetes UK through the clinical lecturers scheme (SGL019/1043).

\section{References}

Abitbol L, Zborovski S \& Palmert MR 2016 Evaluation of delayed puberty: what diagnostic tests should be performed in the seemingly otherwise well adolescent? Archives of Disease in Childhood 101 767771. (https://doi.org/10.1136/archdischild-2015-310375)

Abreu AP, Dauber A, Macedo DB, Noel SD, Brito VN, Gill JC, Cukier P, Thompson IR, Navarro VM, Gagliardi PC, et al. 2013 Central precocious puberty caused by mutations in the imprinted gene MKRN3. New England Journal of Medicine 368 2467-2475. (https:// doi.org/10.1056/NEJMoa1302160)

Abreu AP, Macedo DB, Brito VN, Kaiser UB \& Latronico AC 2015 A new pathway in the control of the initiation of puberty: the MKRN3 gene. Journal of Molecular Endocrinology 54 R131-R139. (https://doi. org/10.1530/JME-14-0315)

Ahmed ML, Ong KK, Morrell DJ, Cox L, Drayer N, Perry L, Preece MA \& Dunger DB 1999 Longitudinal study of leptin concentrations during puberty: sex differences and relationship to changes in body composition. Journal of Clinical Endocrinology and Metabolism 84 899905. (https://doi.org/10.1210/jcem.84.3.5559)

Ahmed K, LaPierre MP, Gasser E, Denzler R, Yang Y, Rulicke T, Kero J, Latreille M \& Stoffel M 2017 Loss of microRNA-7a2 induces hypogonadotropic hypogonadism and infertility. Journal of Clinical Investigation 127 1061-1074. (https://doi.org/10.1172/JCI90031)

Bourguignon JP, Gerard A, Purnelle G, Czajkowski V, Yamanaka C, Lemaitre M, Rigo JM, Moonen G \& Franchimont P 1997 Duality of glutamatergic and GABAergic control of pulsatile GnRH secretion by rat hypothalamic explants: II. Reduced NR2C- and GABAA-receptormediated inhibition at initiation of sexual maturation. Journal of
Neuroendocrinology 9 193-199. (https://doi. org/10.1046/j.1365-2826.1997.00568.x)

Busch AS, Hagen CP, Almstrup K \& Juul A 2016 Circulating MKRN3 levels decline during puberty in healthy boys. Journal of Clinical Endocrinology and Metabolism 101 2588-2593. (https://doi. org/10.1210/jc.2016-1488)

Butler MG 2009 Genomic imprinting disorders in humans: a minireview. Journal of Assisted Reproduction and Genetics 26 477-486. (https://doi.org/10.1007/s10815-009-9353-3)

Cangiano B, Duminuco P, Vezzoli V, Guizzardi F, Chiodini I, Corona G, Maggi M, Persani L \& Bonomi M 2019 Evidence for a common genetic origin of classic and milder adult-onset forms of isolated hypogonadotropic hypogonadism. Journal of Clinical Medicine $\mathbf{8}$ E126. (https://doi.org/10.3390/jcm8010126)

Caronia LM, Martin C, Welt CK, Sykiotis GP, Quinton R, Thambundit A, Avbelj M, Dhruvakumar S, Plummer L, Hughes VA, et al. 2011 A genetic basis for functional hypothalamic amenorrhea. New England Journal of Medicine 364 215-225. (https://doi.org/10.1056/ NEJMoa0911064)

Cassatella D, Howard SR, Acierno JS, Xu C, Papadakis GE, Santoni FA, Dwyer AA, Santini S, Sykiotis GP, Chambion C, et al. 2018 Congenital hypogonadotropic hypogonadism and constitutional delay of growth and puberty have distinct genetic architectures. European Journal of Endocrinology 178 377-388. (https://doi. org/10.1530/EJE-17-0568)

Chan YM, Broder-Fingert S \& Seminara SB 2009 Reproductive functions of kisspeptin and Gpr54 across the life cycle of mice and men. Peptides 30 42-48. (https://doi.org/10.1016/j.peptides.2008.06.015)

Chevrier L, Guimiot F \& de Roux N 2011 GnRH receptor mutations in isolated gonadotropic deficiency. Molecular and Cellular Endocrinology 346 21-28. (https://doi.org/10.1016/j.mce.2011.04.018)

Cioppi F, Riera-Escamilla A, Manilall A, Guarducci E, Todisco T, Corona G, Colombo F, Bonomi M, Flanagan CA \& Krausz C 2019 Genetics of ncHH: from a peculiar inheritance of a novel GNRHR mutation to a comprehensive review of the literature. Andrology 7 88-101. (https://doi.org/10.1111/andr.12563)

Corre C, Shinoda G, Zhu H, Cousminer DL, Crossman C, Bellissimo C, Goldenberg A, Daley GQ \& Palmert MR 2016 Sex-specific regulation of weight and puberty by the Lin28/let-7 axis. Journal of Endocrinology 228 179-191. (https://doi.org/10.1530/JOE-15-0360)

Crino A, Schiaffini R, Ciampalini P, Spera S, Beccaria L, Benzi F, Bosio L, Corrias A, Gargantini L, Salvatoni A, et al. 2003 Hypogonadism and pubertal development in Prader-Willi syndrome. European Journal of Pediatrics 162 327-333. (https://doi. org/10.1007/s00431-002-1132-4)

Dauber A, Cunha-Silva M, Macedo DB, Brito VN, Abreu AP, Roberts SA, Montenegro LR, Andrew M, Kirby A, Weirauch MT, et al. 2017 Paternally inherited DLK1 deletion associated with familial central precocious puberty. Journal of Clinical Endocrinology and Metabolism 102 1557-1567. (https://doi.org/10.1210/jc.2016-3677)

Day FR, Perry JR \& Ong KK 2015 Genetic regulation of puberty timing in humans. Neuroendocrinology 102 247-255. (https://doi. org/10.1159/000431023)

Day FR, Thompson DJ, Helgason H, Chasman DI, Finucane H, Sulem P, Ruth KS, Whalen S, Sarkar AK, Albrecht E, et al. 2017 Genomic analyses identify hundreds of variants associated with age at menarche and support a role for puberty timing in cancer risk. Nature Genetics 49 834-841. (https://doi.org/10.1038/ng.3841)

de Smith AJ, Purmann C, Walters RG, Ellis RJ, Holder SE, Van Haelst MM, Brady AF, Fairbrother UL, Dattani M, Keogh JM, et al. 2009 A deletion of the HBII-85 class of small nucleolar RNAs (snoRNAs) is associated with hyperphagia, obesity and hypogonadism. Human Molecular Genetics 18 3257-3265. (https:// doi.org/10.1093/hmg/ddp263)

Dissen GA, Lomniczi A, Heger S, Neff TL \& Ojeda SR 2012 Hypothalamic EAP1 (enhanced at puberty 1 ) is required for 
menstrual cyclicity in nonhuman primates. Endocrinology 153350 361. (https://doi.org/10.1210/en.2011-1541)

Drobna Z, Henriksen AD, Wolstenholme JT, Montiel C, Lambeth PS, Shang S, Harris EP, Zhou C, Flaws JA, Adli M, et al. 2018 Transgenerational effects of bisphenol A on gene expression and DNA methylation of imprinted genes in brain. Endocrinology 159 132-144. (https://doi.org/10.1210/en.2017-00730)

Dwyer AA, Chavan NR, Lewkowitz-Shpuntoff H, Plummer L, Hayes FJ, Seminara SB, Crowley WF, Pitteloud N \& Balasubramanian R 2019 Functional hypogonadotropic hypogonadism in men: underlying neuroendocrine mechanisms and natural history. Journal of Clinical Endocrinology and Metabolism 104 3403-3414. (https://doi. org/10.1210/jc.2018-02697)

Eaves L, Silberg J, Foley D, Bulik C, Maes H, Erkanli A, Angold A, Costello EJ \& Worthman C 2004 Genetic and environmental influences on the relative timing of pubertal change. Twin Research 7 471-481. (https://doi.org/10.1375/1369052042335278)

Emerick JE \& Vogt KS 2013 Endocrine manifestations and management of Prader-Willi syndrome. International Journal of Pediatric Endocrinology 2013 14. (https://doi.org/10.1186/1687-9856-2013-14)

Farooqi IS 2002 Leptin and the onset of puberty: insights from rodent and human genetics. Seminars in Reproductive Medicine 20 139-144. (https://doi.org/10.1055/s-2002-32505)

Fernandez-Fernandez R, Martini AC, Navarro VM, Castellano JM, Dieguez C, Aguilar E, Pinilla L \& Tena-Sempere M 2006 Novel signals for the integration of energy balance and reproduction. Molecular and Cellular Endocrinology 254-255 127-132. (https://doi. org/10.1016/j.mce.2006.04.026)

Fischer J, Koch L, Emmerling C, Vierkotten J, Peters T, Bruning JC \& Ruther U 2009 Inactivation of the FTO gene protects from obesity. Nature 458 894-898. (https://doi.org/10.1038/nature07848)

Forsythe E \& Beales PL 2013 Bardet-Biedl syndrome. European Journal of Human Genetics 21 8-13. (https://doi.org/10.1038/ejhg.2012.115)

Gabriele M, Vulto-van Silfhout AT, Germain PL, Vitriolo A, Kumar R, Douglas E, Haan E, Kosaki K, Takenouchi T, Rauch A, et al. 2017 YY1 haploinsufficiency causes an intellectual disability syndrome featuring transcriptional and chromatin dysfunction. American Journal of Human Genetics 100 907-925. (https://doi.org/10.1016/j. ajhg.2017.05.006)

Garcia-Mayor RV, Andrade MA, Rios M, Lage M, Dieguez C \& Casanueva FF 1997 Serum leptin levels in normal children: relationship to age, gender, body mass index, pituitary-gonadal hormones, and pubertal stage. Journal of Clinical Endocrinology and Metabolism 82 2849-2855. (https://doi.org/10.1210/jcem.82.9.4235)

Gaudino R, Maines E, Guizzardi F, Vezzoli V, Krausz C, Cavarzere P, Piacentini G, Antoniazzi F \& Bonomi M 2019 45,X/46,X,i(Yp): importance of assessment and support during puberty and adolescence. Sexual Development Epub. (https://doi. org/10.1159/000501377)

Hagen CP, Sorensen K, Mieritz MG, Johannsen TH, Almstrup K \& Juul A 2015 Circulating MKRN3 levels decline prior to pubertal onset and through puberty: a longitudinal study of healthy girls. Journal of Clinical Endocrinology and Metabolism 100 1920-1926. (https://doi. org/10.1210/jc.2014-4462)

He Q \& Karlberg J $2001 \mathrm{Bmi}$ in childhood and its association with height gain, timing of puberty, and final height. Pediatric Research 49 244-251. (https://doi.org/10.1203/00006450-200102000-00019)

Heger S, Mastronardi C, Dissen GA, Lomniczi A, Cabrera R, Roth CL, Jung H, Galimi F, Sippell W \& Ojeda SR 2007 Enhanced at puberty 1 (EAP1) is a new transcriptional regulator of the female neuroendocrine reproductive axis. Journal of Clinical Investigation 117 2145-2154. (https://doi.org/10.1172/JCI31752)

Hirsch HJ, Eldar-Geva T, Bennaroch F, Pollak Y \& Gross-Tsur V 2015 Sexual dichotomy of gonadal function in Prader-Willi syndrome from early infancy through the fourth decade. Human Reproduction 30 2587-2596. (https://doi.org/10.1093/humrep/dev213)
Howard SR, Guasti L, Ruiz-Babot G, Mancini A, David A, Storr HL, Metherell LA, Sternberg MJ, Cabrera CP, Warren HR, et al. 2016 IGSF10 mutations dysregulate gonadotropin-releasing hormone neuronal migration resulting in delayed puberty. ЕMBO Molecular Medicine 8 626-642. (https://doi.org/10.15252/emmm.201606250)

Howard SR, Guasti L, Poliandri A, David A, Cabrera CP, Barnes MR, Wehkalampi K, O'Rahilly S, Aiken CE, Coll AP, et al. 2018a Contributions of function-altering variants in genes implicated in pubertal timing and body mass for self-limited delayed puberty. Journal of Clinical Endocrinology and Metabolism 103 649-659. (https://doi.org/10.1210/jc.2017-02147)

Howard SR, Oleari R, Poliandri A, Chantzara V, Fantin A, Ruiz-Babot G, Metherell LA, Cabrera CP, Barnes MR, Wehkalampi K, et al. 2018b HS6ST1 insufficiency causes self-limited delayed puberty in contrast with other GnRH deficiency genes. Journal of Clinical Endocrinology and Metabolism 103 3420-3429. (https://doi.org/10.1210/jc.201800646)

Jolly A, Bayram Y, Turan S, Aycan Z, Tos T, Abali ZY, Hacihamdioglu B, Coban Akdemir ZH, Hijazi H, Bas S, et al. 2019 Exome sequencing of a primary ovarian insufficiency cohort reveals common molecular etiologies for a spectrum of disease. Journal of Clinical Endocrinology and Metabolism 104 3049-3067. (https://doi.org/10.1210/jc.201900248)

Jong MT, Carey AH, Caldwell KA, Lau MH, Handel MA, Driscoll DJ, Stewart CL, Rinchik EM \& Nicholls RD 1999 Imprinting of a RING zinc-finger encoding gene in the mouse chromosome region homologous to the Prader-Willi syndrome genetic region. Human Molecular Genetics 8 795-803. (https://doi.org/10.1093/hmg/8.5.795)

Kanber D, Giltay J, Wieczorek D, Zogel C, Hochstenbach R, Caliebe A, Kuechler A, Horsthemke B \& Buiting K 2009 A paternal deletion of MKRN3, MAGEL2 and NDN does not result in Prader-Willi syndrome. European Journal of Human Genetics 17 582-590. (https:// doi.org/10.1038/ejhg.2008.232)

Krstevska-Konstantinova M, Charlier C, Craen M, Du Caju M, Heinrichs C, de Beaufort C, Plomteux G \& Bourguignon JP 2001 Sexual precocity after immigration from developing countries to Belgium: evidence of previous exposure to organochlorine pesticides. Human Reproduction 16 1020-1026. (https://doi.org/10.1093/ humrep/16.5.1020)

Kurian JR, Olesen KM \& Auger AP 2010 Sex differences in epigenetic regulation of the estrogen receptor-alpha promoter within the developing preoptic area. Endocrinology 151 2297-2305. (https://doi. org/10.1210/en.2009-0649)

Lanciotti L, Cofini M, Leonardi A, Penta L \& Esposito S 2018 Up-to-date review about minipuberty and overview on hypothalamic-pituitarygonadal axis activation in fetal and neonatal life. Frontiers in Endocrinology 9 410. (https://doi.org/10.3389/fendo.2018.00410)

Lawaetz JG, Hagen CP, Mieritz MG, Blomberg Jensen M, Petersen JH \& Juul A 2015 Evaluation of 451 Danish boys with delayed puberty: diagnostic use of a new puberty nomogram and effects of oral testosterone therapy. Journal of Clinical Endocrinology and Metabolism 100 1376-1385. (https://doi.org/10.1210/jc.2014-3631)

Layman LC, Lee EJ, Peak DB, Namnoum AB, Vu KV, van Lingen BL, Gray MR, McDonough PG, Reindollar RH \& Jameson JL 1997 Delayed puberty and hypogonadism caused by mutations in the follicle-stimulating hormone beta-subunit gene. New England Journal of Medicine 337 607-611. (https://doi.org/10.1056/ NEJM199708283370905)

Lee HS \& Hwang JS 2013 Central precocious puberty in a girl with Prader-Willi syndrome. Journal of Pediatric Endocrinology and Metabolism 26 1201-1204. (https://doi.org/10.1515/jpem-20130040)

Lee BJ, Cho GJ, Norgren Jr RB, Junier MP, Hill DF, Tapia V, Costa ME \& Ojeda SR 2001 TTF-1, a homeodomain gene required for diencephalic morphogenesis, is postnatally expressed in the neuroendocrine brain in a developmentally regulated and cell- 
specific fashion. Molecular and Cellular Neurosciences 17 107-126. (https://doi.org/10.1006/mcne.2000.0933)

Li C \& Li P 2017 Enhanced at Puberty-1 (Eap1) expression critically regulates the onset of puberty independent of hypothalamic Kiss1 expression. Cellular Physiology and Biochemistry 43 1402-1412. (https://doi.org/10.1159/000481872)

Li X, Sun Z, Manthari RK, Li M, Guo Q \& Wang J 2018 Effect of gestational exposure to arsenic on puberty in offspring female mice. Chemosphere 202 119-126. (https://doi.org/10.1016/j. chemosphere.2018.03.095)

Lin L, Conway GS, Hill NR, Dattani MT, Hindmarsh PC \& Achermann JC 2006 A homozygous R262Q mutation in the gonadotropin-releasing hormone receptor presenting as constitutional delay of growth and puberty with subsequent borderline oligospermia. Journal of Clinical Endocrinology and Metabolism 91 5117-5121. (https://doi.org/10.1210/jc.2006-0807)

Liu B, Liu M, Wang J, Zhang X, Wang X, Wang P, Wang H, Li W \& Wang Y 2015 DICER-dependent biogenesis of let-7 miRNAs affects human cell response to DNA damage via targeting p21/p27. Nucleic Acids Research 43 1626-1636. (https://doi.org/10.1093/nar/gku1368)

Lomniczi A \& Ojeda SR 2016 The emerging role of epigenetics in the regulation of female puberty. Endocrine Development 29 1-16. (https://doi.org/10.1159/000438840)

Lomniczi A, Garcia-Rudaz C, Ramakrishnan R, Wilmot B, Khouangsathiene S, Ferguson B, Dissen GA \& Ojeda SR 2012 A single-nucleotide polymorphism in the EAP1 gene is associated with amenorrhea/oligomenorrhea in nonhuman primates. Endocrinology 153 339-349. (https://doi.org/10.1210/en.2011-1540)

Lomniczi A, Loche A, Castellano JM, Ronnekleiv OK, Bosch M, Kaidar G, Knoll JG, Wright H, Pfeifer GP \& Ojeda SR 2013 Epigenetic control of female puberty. Nature Neuroscience 16 281-289. (https:// doi.org/10.1038/nn.3319)

Lomniczi A, Wright H, Castellano JM, Matagne V, Toro CA, Ramaswamy S, Plant TM \& Ojeda SR 2015 Epigenetic regulation of puberty via zinc finger protein-mediated transcriptional repression. Nature Communications 6 10195. (https://doi.org/10.1038/ ncomms10195)

Mancini A, Howard SR, Cabrera CP, Barnes MR, David A, Wehkalampi K, Heger S, Lomniczi A, Guasti L, Ojeda SR, et al. 2019 EAP1 regulation of GnRH promoter activity is important for human pubertal timing. Human Molecular Genetics 28 1357-1368. (https://doi.org/10.1093/ hmg/ddy451)

Manfredi-Lozano M, Roa J, Ruiz-Pino F, Piet R, Garcia-Galiano D, Pineda R, Zamora A, Leon S, Sanchez-Garrido MA, Romero-Ruiz A, et al. 2016 Defining a novel leptin-melanocortin-kisspeptin pathway involved in the metabolic control of puberty. Molecular Metabolism 5 844-857. (https://doi.org/10.1016/j.molmet.2016.08.003)

Martinez de Morentin PB, Martinez-Sanchez N, Roa J, Ferno J, Nogueiras R, Tena-Sempere M, Dieguez C \& Lopez M 2014 Hypothalamic mTOR: the rookie energy sensor. Current Molecular Medicine 14 3-21. (https://doi.org/10.2174/156652401366613111810 3706)

Mastronardi C, Smiley GG, Raber J, Kusakabe T, Kawaguchi A, Matagne V, Dietzel A, Heger S, Mungenast AE, Cabrera R, et al. 2006 Deletion of the Ttf1 gene in differentiated neurons disrupts female reproduction without impairing basal ganglia function. Journal of Neuroscience 26 13167-13179. (https://doi.org/10.1523/ JNEUROSCI.4238-06.2006)

McMurray F, Church CD, Larder R, Nicholson G, Wells S, Teboul L, Tung YC, Rimmington D, Bosch F, Jimenez V, et al. 2013 Adult onset global loss of the FTO gene alters body composition and metabolism in the mouse. PLoS Genetics 9 e1003166. (https://doi.org/10.1371/ journal.pgen.1003166)

Merkestein M, Laber S, McMurray F, Andrew D, Sachse G, Sanderson J, Li M, Usher S, Sellayah D, Ashcroft FM, et al. 2015 FTO influences adipogenesis by regulating mitotic clonal expansion. Nature Communications 6 6792. (https://doi.org/10.1038/ncomms7792)

Messina A, Langlet F, Chachlaki K, Roa J, Rasika S, Jouy N, Gallet S, Gaytan F, Parkash J, Tena-Sempere M, et al. 2016 A microRNA switch regulates the rise in hypothalamic GnRH production before puberty. Nature Neuroscience 19 835-844. (https://doi.org/10.1038/nn.4298)

Milesi MM, Lorenz V, Pacini G, Repetti MR, Demonte LD, Varayoud J \& Luque EH 2018 Perinatal exposure to a glyphosate-based herbicide impairs female reproductive outcomes and induces secondgeneration adverse effects in Wistar rats. Archives of Toxicology 92 2629-2643. (https://doi.org/10.1007/s00204-018-2236-6)

Morris DH, Jones ME, Schoemaker MJ, Ashworth A \& Swerdlow AJ 2011 Familial concordance for age at menarche: analyses from the Breakthrough Generations Study. Paediatric and Perinatal Epidemiology 25 306-311. (https://doi.org/10.1111/j.1365-3016.2010.01183.x)

Morrison KE, Rodgers AB, Morgan CP \& Bale TL 2014 Epigenetic mechanisms in pubertal brain maturation. Neuroscience 264 17-24. (https://doi.org/10.1016/j.neuroscience.2013.11.014)

Mouritsen A, Aksglaede L, Sorensen K, Mogensen SS, Leffers H, Main KM, Frederiksen H, Andersson AM, Skakkebaek NE \& Juul A 2010 Hypothesis: exposure to endocrine-disrupting chemicals may interfere with timing of puberty. International Journal of Andrology $\mathbf{3 3}$ 346-359. (https://doi.org/10.1111/j.1365-2605.2010.01051.x)

Mueller JK, Koch I, Lomniczi A, Loche A, Rulfs T, Castellano JM, Kiess W, Ojeda S \& Heger S 2012 Transcription of the human EAP1 gene is regulated by upstream components of a puberty-controlling tumor suppressor gene network. Molecular and Cellular Endocrinology 351 184-198. (https://doi.org/10.1016/j.mce.2011.12.004)

Narayan P 2015 Genetic models for the study of luteinizing hormone receptor function. Frontiers in Endocrinology 6 152. (https://doi. org/10.3389/fendo.2015.00152)

Nilsson E, King SE, McBirney M, Kubsad D, Pappalardo M, Beck D, Sadler-Riggleman I \& Skinner MK 2018 Vinclozolin induced epigenetic transgenerational inheritance of pathologies and sperm epimutation biomarkers for specific diseases. PLOS ONE 13 e0202662. (https://doi.org/10.1371/journal.pone.0202662)

Nunziata A, Funcke JB, Borck G, von Schnurbein J, Brandt S, Lennerz B, Moepps B, Gierschik P, Fischer-Posovszky P \& Wabitsch M 2019 Functional and phenotypic characteristics of human leptin receptor mutations. Journal of the Endocrine Society 3 27-41. (https://doi. org/10.1210/js.2018-00123)

Ojeda SR, Hill J, Hill DF, Costa ME, Tapia V, Cornea A \& Ma YJ 1999 The Oct-2 POU domain gene in the neuroendocrine brain: a transcriptional regulator of mammalian puberty. Endocrinology 140 3774-3789. (https://doi.org/10.1210/endo.140.8.6941)

Ojeda SR, Lomniczi A, Mastronardi C, Heger S, Roth C, Parent AS, Matagne V \& Mungenast AE 2006 Minireview: the neuroendocrine regulation of puberty: is the time ripe for a systems biology approach? Endocrinology 147 1166-1174. (https://doi.org/10.1210/ en.2005-1136)

Ojeda SR, Dubay C, Lomniczi A, Kaidar G, Matagne V, Sandau US \& Dissen GA 2010 Gene networks and the neuroendocrine regulation of puberty. Molecular and Cellular Endocrinology 324 3-11. (https:// doi.org/10.1016/j.mce.2009.12.003)

Ong KK, Elks CE, Li S, Zhao JH, Luan J, Andersen LB, Bingham SA, Brage S, Smith GD, Ekelund U, et al. 2009 Genetic variation in LIN28B is associated with the timing of puberty. Nature Genetics $\mathbf{4 1}$ 729-733. (https://doi.org/10.1038/ng.382)

Owen BM, Bookout AL, Ding X, Lin VY, Atkin SD, Gautron L, Kliewer SA \& Mangelsdorf DJ 2013 FGF21 contributes to neuroendocrine control of female reproduction. Nature Medicine 19 1153-1156. (https://doi.org/10.1038/nm.3250)

Palmert MR \& Dunkel L 2012 Clinical practice. Delayed puberty. New England Journal of Medicine 366 443-453. (https://doi.org/10.1056/ NEJMcp1109290)
(C) 2019 Society for Endocrinology Published by Bioscientifica Ltd. Printed in Great Britain 
Parent AS, Franssen D, Fudvoye J, Gerard A \& Bourguignon JP 2015 Developmental variations in environmental influences including endocrine disruptors on pubertal timing and neuroendocrine control: revision of human observations and mechanistic insight from rodents. Frontiers in Neuroendocrinology 38 12-36. (https://doi. org/10.1016/j.yfrne.2014.12.004)

Parkash J, Messina A, Langlet F, Cimino I, Loyens A, Mazur D, Gallet S, Balland E, Malone SA, Pralong F, et al. 2015 Semaphorin7A regulates neuroglial plasticity in the adult hypothalamic median eminence. Nature Communications 6 6385. (https://doi.org/10.1038/ ncomms7385)

Peters J 2014 The role of genomic imprinting in biology and disease: an expanding view. Nature Reviews: Genetics 15 517-530. (https://doi. org/10.1038/nrg3766)

Pielecka-Fortuna J, Chu Z \& Moenter SM 2008 Kisspeptin acts directly and indirectly to increase gonadotropin-releasing hormone neuron activity and its effects are modulated by estradiol. Endocrinology 149 1979-1986. (https://doi.org/10.1210/en.2007-1365)

Pinson A, Franssen D, Gerard A, Parent AS \& Bourguignon JP 2017 Neuroendocrine disruption without direct endocrine mode of action: polychloro-biphenyls (PCbs) and bisphenol A (BPA) as case studies. Comptes Rendus Biologies 340 432-438. (https://doi.org/10.1016/j. crvi.2017.07.006)

Pitteloud N, Boepple PA, DeCruz S, Valkenburgh SB, Crowley Jr WF \& Hayes FJ 2001 The fertile eunuch variant of idiopathic hypogonadotropic hypogonadism: spontaneous reversal associated with a homozygous mutation in the gonadotropin-releasing hormone receptor. Journal of Clinical Endocrinology and Metabolism $\mathbf{8 6}$ 2470-2475. (https://doi.org/10.1210/jcem.86.6.7542)

Pitteloud N, Meysing A, Quinton R, Acierno Jr JS, Dwyer AA, Plummer L, Fliers E, Boepple P, Hayes F, Seminara S, et al. 2006 Mutations in fibroblast growth factor receptor 1 cause Kallmann syndrome with a wide spectrum of reproductive phenotypes. Molecular and Cellular Endocrinology 254-255 60-69. (https://doi. org/10.1016/j.mce.2006.04.021)

Pitteloud N, Quinton R, Pearce S, Raivio T, Acierno J, Dwyer A, Plummer L, Hughes V, Seminara S, Cheng YZ, et al. 2007 Digenic mutations account for variable phenotypes in idiopathic hypogonadotropic hypogonadism. Journal of Clinical Investigation 117 457-463. (https://doi.org/10.1172/JCI29884)

Plant TM 2015 Neuroendocrine control of the onset of puberty. Frontiers in Neuroendocrinology 38 73-88. (https://doi.org/10.1016/j. yfrne.2015.04.002)

Plant TM \& Barker-Gibb ML 2004 Neurobiological mechanisms of puberty in higher primates. Human Reproduction Update 10 67-77. (https://doi.org/10.1093/humupd/dmh001)

Pomerants T, Tillmann V, Karelson K, Jurimae J \& Jurimae T 2006 Ghrelin response to acute aerobic exercise in boys at different stages of puberty. Hormone and Metabolic Research 38 752-757. (https://doi. org/10.1055/s-2006-955087)

Potorac I, Rivero-Muller A, Trehan A, Kielbus M, Jozwiak K, Pralong F, Hafidi A, Thiry A, Menage JJ, Huhtaniemi I, et al. 2016 A vital region for human glycoprotein hormone trafficking revealed by an LHB mutation. Journal of Endocrinology 231 197-207. (https://doi. org/10.1530/JOE-16-0384)

Pugliese-Pires PN, Fortin JP, Arthur T, Latronico AC, Mendonca BB Villares SM, Arnhold IJ, Kopin AS \& Jorge AA 2011 Novel inactivating mutations in the GH secretagogue receptor gene in patients with constitutional delay of growth and puberty. European Journal of Endocrinology 165 233-241. (https://doi.org/10.1530/EJE11-0168)

Rissman EF \& Adli M 2014 Minireview: transgenerational epigenetic inheritance: focus on endocrine disrupting compounds. Endocrinology 155 2770-2780. (https://doi.org/10.1210/en.2014-1123)

Sedlmeyer IL \& Palmert MR 2002 Delayed puberty: analysis of a large case series from an academic center. Journal of Clinical Endocrinology and Metabolism 87 1613-1620. (https://doi.org/10.1210/ jcem.87.4.8395)

Sedlmeyer IL, Hirschhorn JN \& Palmert MR 2002 Pedigree analysis of constitutional delay of growth and maturation: determination of familial aggregation and inheritance patterns. Journal of Clinical Endocrinology and Metabolism 87 5581-5586. (https://doi. org/10.1210/jc.2002-020862)

Silveira LG, Noel SD, Silveira-Neto AP, Abreu AP, Brito VN, Santos MG, Bianco SD, Kuohung W, Xu S, Gryngarten M, et al. 2010 Mutations of the KISS1 gene in disorders of puberty. Journal of Clinical Endocrinology and Metabolism 95 2276-2280. (https://doi. org/10.1210/jc.2009-2421)

Silveira-Neto AP, Leal LF, Emerman AB, Henderson KD, Piskounova E, Henderson BE, Gregory RI, Silveira LF, Hirschhorn JN, Nguyen TT, et al. 2012 Absence of functional LIN28B mutations in a large cohort of patients with idiopathic central precocious puberty. Hormone Research in Paediatrics 78 144-150. (https://doi. org/10.1159/000342212)

Simon D, Ba I, Mekhail N, Ecosse E, Paulsen A, Zenaty D, Houang M, Jesuran Perelroizen M, de Filippo GP, Salerno M, et al. 2016 Mutations in the maternally imprinted gene MKRN3 are common in familial central precocious puberty. European Journal of Endocrinology 174 1-8. (https://doi.org/10.1530/EJE-15-0488)

Sorensen K, Aksglaede L, Petersen JH \& Juul A 2010 Recent changes in pubertal timing in healthy Danish boys: associations with body mass index. Journal of Clinical Endocrinology and Metabolism 95 263-270. (https://doi.org/10.1210/jc.2009-1478)

Speakman JR 2015 The 'Fat Mass and Obesity Related' (FTO) gene: mechanisms of impact on obesity and energy balance. Current Obesity Reports 4 73-91. (https://doi.org/10.1007/s13679-0150143-1)

Swan SH, Main KM, Liu F, Stewart SL, Kruse RL, Calafat AM, Mao CS, Redmon JB, Ternand CL, Sullivan S, et al. 2005 Decrease in anogenital distance among male infants with prenatal phthalate exposure. Environmental Health Perspectives 113 1056-1061. (https:// doi.org/10.1289/ehp.8100)

Szymanska K, Kalafut J \& Rivero-Muller A 2018 The gonadotropin system, lessons from animal models and clinical cases. Minerva Ginecologica 70 561-587. (https://doi.org/10.23736/S00264784.18.04307-1)

Themmen APN \& Huhtaniemi IT 2000 Mutations of gonadotropins and gonadotropin receptors: elucidating the physiology and pathophysiology of pituitary-gonadal function. Endocrine Reviews $\mathbf{2 1}$ 551-583. (https://doi.org/10.1210/edrv.21.5.0409)

Tommiska J, Wehkalampi K, Vaaralahti K, Laitinen EM, Raivio T \& Dunkel L 2010 LIN28B in constitutional delay of growth and puberty. Journal of Clinical Endocrinology and Metabolism 95 30633066. (https://doi.org/10.1210/jc.2009-2344)

Topaloglu AK, Tello JA, Kotan LD, Ozbek MN, Yilmaz MB, Erdogan S, Gurbuz F, Temiz F, Millar RP \& Yuksel B 2012 Inactivating KISS1 mutation and hypogonadotropic hypogonadism. New England Journal of Medicine 366 629-635. (https://doi.org/10.1056/ NEJMoa1111184)

Tornberg J, Sykiotis GP, Keefe K, Plummer L, Hoang X, Hall JE, Quinton R, Seminara SB, Hughes V, Van Vliet G, et al. 2011 Heparan sulfate 6-O-sulfotransferase 1 , a gene involved in extracellular sugar modifications, is mutated in patients with idiopathic hypogonadotrophic hypogonadism. PNAS 108 11524-11529. (https://doi.org/10.1073/pnas.1102284108)

Toro CA, Wright H, Aylwin CF, Ojeda SR \& Lomniczi A 2018 Trithorax dependent changes in chromatin landscape at enhancer and promoter regions drive female puberty. Nature Communications 957 (https://doi.org/10.1038/s41467-017-02512-1)

Turner G, Lower KM, White SM, Delatycki M, Lampe AK, Wright M, Smith JC, Kerr B, Schelley S, Hoyme HE, et al. 2004 The clinical picture of the Borjeson-Forssman-Lehmann syndrome in males and 
heterozygous females with PHF6 mutations. Clinical Genetics 65 226232. (https://doi.org/10.1111/j.0009-9163.2004.00215.x)

Vaaralahti K, Wehkalampi K, Tommiska J, Laitinen EM, Dunkel L \& Raivio T 2011 The role of gene defects underlying isolated hypogonadotropic hypogonadism in patients with constitutional delay of growth and puberty. Fertility and Sterility 95 2756-2758. (https://doi.org/10.1016/j.fertnstert.2010.12.059)

van den Berg SM, Setiawan A, Bartels M, Polderman TJ, van der Vaart AW \& Boomsma DI 2006 Individual differences in puberty onset in girls: bayesian estimation of heritabilities and genetic correlations. Behavior Genetics 36 261-270. (https://doi.org/10.1007/ s10519-005-9022-y)

van den Driesche S, Macdonald J, Anderson RA, Johnston ZC, Chetty T, Smith LB, McKinnell C, Dean A, Homer NZ, Jorgensen A, et al. 2015 Prolonged exposure to acetaminophen reduces testosterone production by the human fetal testis in a xenograft model. Science Translational Medicine 7 288ra80. (https://doi.org/10.1126/ scitranslmed.aaa4097)

Vazquez MJ, Toro CA, Castellano JM, Ruiz-Pino F, Roa J, Beiroa D, Heras V, Velasco I, Dieguez C, Pinilla L, et al. 2018 SIRT1 mediates obesity- and nutrient-dependent perturbation of pubertal timing by epigenetically controlling Kiss1 expression. Nature Communications 9 4194. (https://doi.org/10.1038/s41467-018-06459-9)

Wang Y 2002 Is obesity associated with early sexual maturation? A comparison of the association in American boys versus girls. Pediatrics 110 903-910. (https://doi.org/10.1542/peds.110.5.903)

Wehkalampi K, Widen E, Laine T, Palotie A \& Dunkel L 2008 Patterns of inheritance of constitutional delay of growth and puberty in families of adolescent girls and boys referred to specialist pediatric care. Journal of Clinical Endocrinology and Metabolism 93 723-728. (https:// doi.org/10.1210/jc.2007-1786)

Winter S, Ousidhoum A, McElreavey K \& Brauner R 2016 Constitutional delay of puberty: presentation and inheritance pattern in 48 familial cases. BMC Pediatrics 16 37. (https://doi.org/10.1186/s12887-0160580-3)

Xu J \& Li P 2016 Expression of EAP1 and CUX1 in the hypothalamus of female rats and relationship with KISS1 and GnRH. Endocrine Journal 63 681-690. (https://doi.org/10.1507/endocrj.EJ16-0123)

Xu C, Messina A, Somm E, Miraoui H, Kinnunen T, Acierno Jr J, Niederlander NJ, Bouilly J, Dwyer AA, Sidis Y, et al. 2017 KLB, encoding beta-klotho, is mutated in patients with congenital hypogonadotropic hypogonadism. EMBO Molecular Medicine 9 1379_ 1397. (https://doi.org/10.15252/emmm.201607376)

Yang C, Ye J, Li X, Gao X, Zhang K, Luo L, Ding J, Zhang Y, Li Y, Cao H, et al. 2016 DNA methylation patterns in the hypothalamus of female pubertal goats. PLOS ONE 11 e0165327. (https://doi.org/10.1371/ journal.pone.0165327)

Yeo GS 2014 The role of the FTO (Fat Mass and Obesity Related) locus in regulating body size and composition. Molecular and Cellular Endocrinology 397 34-41. (https://doi.org/10.1016/j. mce.2014.09.012)

Zhu J, Choa RE, Guo MH, Plummer L, Buck C, Palmert MR, Hirschhorn JN, Seminara SB \& Chan YM 2015 A shared genetic basis for self-limited delayed puberty and idiopathic hypogonadotropic hypogonadism. Journal of Clinical Endocrinology and Metabolism 100 E646-E654. (https://doi.org/10.1210/jc.2015-1080)

Received in final form 30 June 2019

Accepted 7 August 2019

Accepted Preprint published online 8 August 2019
(C) 2019 Society for Endocrinology Published by Bioscientifica Ltd. Printed in Great Britain 